\title{
First Re-Os age dating of molybdenite from Babyak Mo-Ag-Au-W-Bi-base metal deposit: evidence for Early Eocene fertile magmatic-hydrothermal system in Western Rhodopes, Bulgaria
}

\section{Първи Re-Os датировки на молибденит от Mo-Ag-Au-W-Bi-полиметално находище Бабяк: доказателства за ранноеоенска рудоносна магматично-хидротермална система в Западни Родопи, България}

\author{
Milen Stavrev ${ }^{1}$, Robert Creaser ${ }^{2}$, Irena Peytcheva ${ }^{1}$, Atanas Hikov ${ }^{1}$, Silvia Chavdarova ${ }^{1}$ \\ Милен Ставревㅁ, Робърт Крийсър ${ }^{2}$, Ирена Пейчева ${ }^{1}$, Атанас Хиков ${ }^{1}$, Силвия Чавдарова ${ }^{1}$ \\ ${ }^{1}$ Geological Institute, Bulgarian Academy of Sciences, Acad. G. Bonchev str., bl. 24, 1113 Sofia; E-mail: mstavrev@geology.bas.bg \\ ${ }^{2}$ Department of Earth and Atmospheric Sciences, 1-26 ESB, University of Alberta, Edmonton, AB, Canada T6G 2E3
}

Keywords: molybdenite, EPMA, LA-ICP-MS, Re-Os dating, Western Rhodopes.

\section{Introduction}

The Rhodopes are one of the main tectono-metallogenic units in Bulgaria and on the Balkan Peninsula with a diversity of world class $\mathrm{Pb}-\mathrm{Zn}$ and Au-base metal ore deposits of different origin. According to modern concepts, the Rhodopes are considered an Alpine south-vergent syn-metamorphic nappe structure associated with late- to post-collisional extensional faulting (Ivanov, 2017). The Alpine evolution in the western parts of the massif is dominated by intensive granitoid magmatism related to forming of large-scale plutons such as Rila-West Rhodopes batholith (RWRB). This magmatic activity produced Late Cretaceous-Paleogene ore mineralization (Popov, Popov, 2019). The RWRB is a complex pluton consisting of granodiorites to granites with distinct composition as well as with different age (Valkov et al., 1989; Kamenov et al., 1999; von Quadt, Peytcheva, 2005, Stavrev et al., 2020). Numerous mafic to felsic dykes are intruded into the batholith.

Here, we present first Re-Os age data of molybdenite from Babyak Mo-Ag-Au-W-Bi-base metal deposit, one of the ore-bearing areas in the RWRB. They are compiled with detailed electron microprobe (EMPA) and laser ablation inductively coupled plasma mass spectrometry (LA-ICP-MS) results for molybdenite aggregates. The main aim of this paper is to clarify the temporal and spatial relationships between the magmatic-hydrothermal sequence of events related to ore deposition at the Babyak area. The new data for the molybdenite chemistry may have economic significance during future exploration and extracting works.

\section{Geological background}

The area of the Babyak Mo-Ag-Au-W-Bi-base metal ore deposit (Deltchev, Dimitrov, 1964; Popov, Popov, 2019) is situated about $180 \mathrm{~km} \mathrm{SE}$ of Sofia. District geology is dominated by Upper Cretaceous granites (Stavrev et al., 2020) from the RWRB and related pegmatites ( \pm aplitic veins) that are intruded into variegated metamorphic basement comprising gneisses, schists, marbles and amphibolites of the Jurassic Sarnitsa lithotectonic unit (Sarov et al., 2010). A small dike-like dioritic, quartz dioritic and spessartitic bodies are rarely outcropped (Sarov et al., 2010). The mineralized zones at Babyak are hosted in the contact zones between granites/ pegmatites and gneisses or cross-cut the different lithologies. Both host rocks are overprinted by moderate to strong wall-rock alterations. The deposit is attached to NNE-SSW faults as well secondary NW-SE faults, some of them related to the main tectonic structure in the region - Babyak-Grashevo shear zone (BGSZ; Sarov et al., 2010). Mineralization styles include sulfide and sulfosalt veinlets, disseminations and nests mainly within brittle veins with quartz to quartz-pegmatite composition. Molybdenite and pyrite are the major ore minerals, whereas sphalerite, galena, chalcopyrite, bismuthinite, $\mathrm{Pb}-\mathrm{Bi}$ sulfosalts, \pm magnetite, \pm tungstenite, \pm scheelite, \pm arsenopyrite, \pm rutile, \pm native gold, etc. are subordinate (Deltchev, Dimitrov, 1964; Stavrev et al., 2018). The alteration zones are represented by phyllic, silicification and greisen-like types, locally skarns, argillic alteration, carbonatization and zeolitization occur (Stavrev et al., 2018). 


\section{Samples and analytical methods}

This study is based on the chemistry of 6 molybdenite-bearing samples from 5 drill holes as well as 2 drill-hole samples for Re-Os age dating from the main hydrothermal alteration/ore zones at the Babyak deposit. The mineral associations and relationships were studied by means of polarizing microscope and scanning-electron microscopy (SEM). The major elements in the analyzed molybdenite flakes were determined by EPMA using SEM JEOL JSM-6610LV at the University of Belgrade, Serbia. Trace elements were measured by LA-ICP-MS (PerkinElmer ELAN DRC-e ICP-MS with a New Wave UP193FX LA system) at the Geological Institute, Bulgarian Academy of Sciences. The Re-Os dating of molybdenite was performed at the Department of Earth and Atmospheric Sciences, University of Alberta, Edmonton, Canada. The ${ }^{187} \mathrm{Re}$ and ${ }^{187}$ Os concentrations were obtained by isotope dilution mass spectrometry using Carius-tube, solvent extraction, anion chromatography and negative thermal ionization mass spectrometry (NTIMS) techniques (see, Selby, Creaser, 2004, for details).

\section{Results}

Molybdenite in all analyzed samples occurs usually as $\mu \mathrm{m}$ - to $\mathrm{mm}$-scale closely intergrowth lamellar aggregates as well as rarer fine single flakes or disseminations. They occur most common as bendings and kinks deposited mainly in the contacts of grey to white quartz veinlets and larger veins. Molybdenite is observed within granites and pegmatites and mostly associates with pyrite, white micas (muscovite to sericite), $\mathrm{Pb}$-Bi sulfosalts, chalcopyrite, fluorite, sometimes with magnetite, chlorite, galena or sphalerite.

The Re-Os geochronology of the two molybdenite samples defines early Eocene age for the mineralization at Babyak deposit. The first sample $(1575 / 479.10)$ from the eastern part of the deposit is separated from a $2 \mathrm{~cm}$ wide quartz-molybdenite vein (with pyrite, chalcopyrite, etc.) in the granites and shows a model Re-Os age $53 \pm 0.2 \mathrm{Ma}$. Another sample (1307/188.40) from the western part of the deposit consists of mm-sized molybdenite ( \pm pyrite) that fills cracks in the pegmatites. Its age is defined at $52.6 \pm 0.2 \mathrm{Ma}$. The Re content in the samples is low - 16-20 ppm.

Comprehensive results for molybdenite composition are obtained from 20 EPMA and 34 LA-ICPMS analyses. The EPMA data show relatively homogeneous Mo (60.43-62.31 wt\%) and S (37.69$39.56 \mathrm{wt} \%$ ) content based on which the following formula is calculated: $\mathrm{Mo}_{1.01-1.07} \mathrm{~S}_{1.93-1.99}$. The LAICP-MS study revealed wide variations of trace elements (in ppm) in molybdenite: $\mathrm{Pb}$ (1-9900, avg.
2200), Bi (1-8600, avg. 830), Ag (2-1975, avg. 159), W (7-30, avg. 16), Re (4-115, avg. 41), Cd (96-174, avg. 133), In (43-73, avg. 57), Nb (4-41, avg. 9), Ti (121-1392, avg. 244). Other typical impurities with variable concentration from limit of detection (LOD) to measured values are (in ppm) Fe (up to 46260 ), Ba (up to 1940), V (up to 446), $\mathrm{Mn}$ (2750), Sr (up to 214), Cu (up to 1300), Te (up to 23 ), $\mathrm{Sb}$ (up to 16). The depth profile of signals for all trace elements suggests either distribution as micro-inclusions or incorporations in the molybdenite structure (Fig. 1).

\section{Discussion and conclusions}

The LA-ICP-MS trace element data for molybdenites reveal significant positive correlation $(0.82)$ between $\mathrm{Pb}$ and $\mathrm{Bi}$. Similar behavior is observed for $\mathrm{Ag}$ that has relatively positive correlation with $\mathrm{Pb}$ (0.41) and ambiguous with $\mathrm{Bi}(0.38)$. These peculiarities are most likely due to $\mathrm{Ag}$-bearing fine $\mathrm{Pb}-\mathrm{Bi}$ sulfosalt and rarely galena "inclusion-like" lamellas or disseminations in the inter-lamellar space of the molybdenite crystals (Fig. 1a). On the other hand, the flat distribution of $\mathrm{Pb}, \mathrm{Bi}$ and $\mathrm{Ag}$ in the laser ablation depth-profiles (Fig. 1b) argues for their homogeneous incorporation in the molybdenite and may be attributed to lattice-defects, as suggested by Ciobanu et al. (2013). The contents of Cu, Cd, In, Te and $\mathrm{Sb}$ suggest coexistence in sulfosalt inclusions.

The Re is a typical substitution element of Mo but in the Babyak molybdenites is non-homogeneously distributed (Fig. 1a, b) and in low content compared with typical values in porphyry-copper deposits. The $\mathrm{W}$ is considered a specific isomorphic element in molybdenite, however in the studied samples it has a contrasting behavior and rather reveals affinity to $\mathrm{V}$ - and $\mathrm{Fe}$-bearing micro-inclusions. The strong positive correlations of $\mathrm{Ba}$ with $\mathrm{Ti}(0.84)$, $\mathrm{V}(0.83), \mathrm{Fe}(0.84)$, of Ti with Fe (0.99), V (0.96) and of $\mathrm{V}$ with $\mathrm{Fe}(0.99)$ infers close intergrowths of the molybdenite flakes with silicates such as white micas that often associate with them. Positive correlation coefficients of $\mathrm{Nb}$ with $\mathrm{Ti}(0.79), \mathrm{V}(0.76)$, $\mathrm{Fe}(0.75)$ and $\mathrm{Ba}(0.63)$ may be attributed to the same minerals and/or unknown Nb-bearing phases.

The new Re-Os age data of molybdenite for the region at Babyak Mo-Ag-Au-W-Bi-base metal deposit mark a distinct fertile early Eocene 52.453.2 Ma event in the Cretaceous-Paleogene evolution of the RWRB. So far at least two episodes associated with the magmatic-hydrothermal systems are recognized within the deposit: 1) Upper Cretaceous granites $71.12 \pm 0.72 \mathrm{Ma}$ and sparse elongated to irregular quartz diorite bodies $(71.35 \pm 0.58 \mathrm{Ma})$, associated with skarn-type mineralization dated at

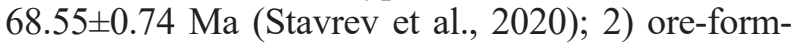



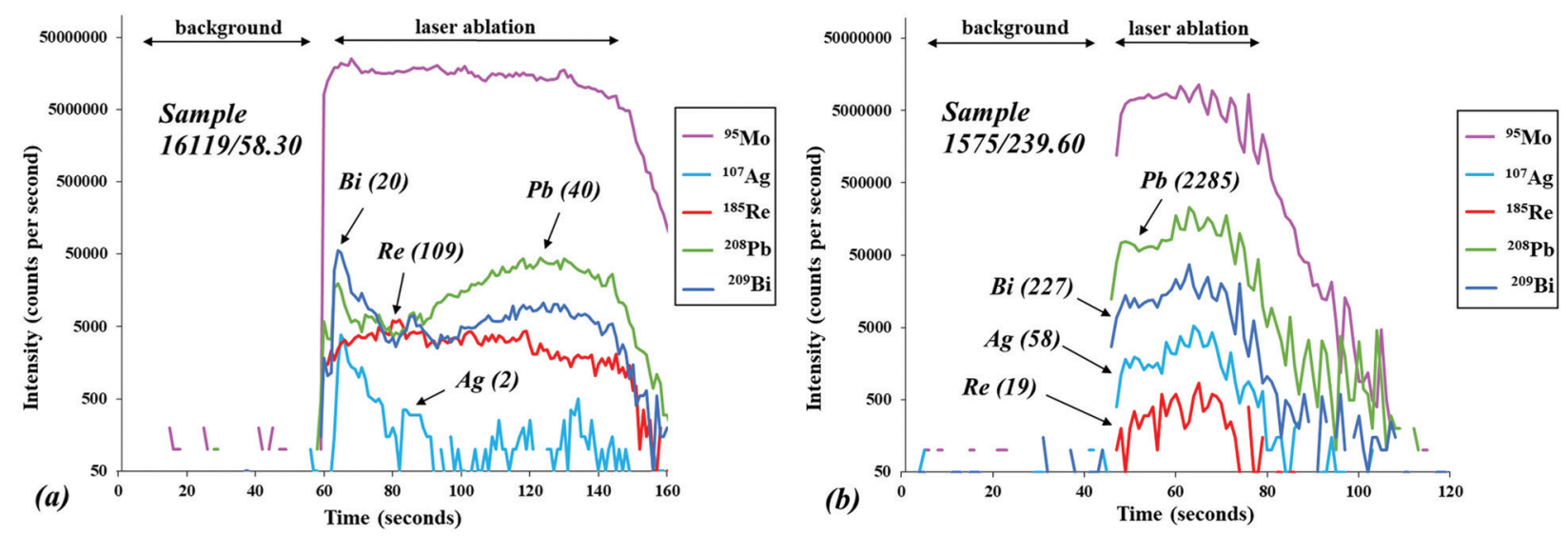

Fig. 1. Time-resolved LA-ICP-MS depth profiles for some of the widespread trace elements in molybdenite from Babyak deposit: $a, \mathrm{~Pb}, \mathrm{Bi}$ and $\mathrm{Ag}$ in micro-inclusions as well as isomorphous Re (sample 16119/58.30); $b$, similar distribution between $\mathrm{Mo}, \mathrm{Pb}, \mathrm{Bi}$, $\mathrm{Ag}$ and Re spectra, suggesting incorporation in the molybdenite lattice (sample 1575/239.60). Element concentrations (in ppm) are given in brackets.

ing and molybdenite-bearing processes at $\sim 53 \mathrm{Ma}$. However, Eocene magmatism is characteristic for the metamorphic unites of the Middle Allochthone in the Rhodope metamorphic complex (e.g., Sarov et al., 2010) and was recently defined for the granites of the RWRB south of the BGSZ (Peytcheva et al., this volume). This magmatism is defined potentially fertile by the adakite-like characteristics of the outcropped granitoids in the Rhodopes (Marchev et al., 2013). At this stage of investigations of the Babyak deposit area we can still not estimate the significance of the main episode of Late Alpine magmatism $\sim 40 \mathrm{Ma}$ of the RWRB. Field and drill cores observations, as well as earlier studies (e.g., Deltchev, Dimitrov, 1964; Stavrev et al., 2018) suggest intensive multistage post-magmatic hydrothermal processes in the Babyak region and it cannot be excluded younger (Oligocene?) magmatic-hydrothermal system as source the base metals and Au. Further geochronological studies on alteration minerals of the deposit and granites of the RWRB and its closest frame may shed light on the distinction of late alteration/ore minerals stages and the feeder center of ore components.

Acknowledgements: MS thanks the Society of Economic Geologists Foundation (SEGF) for a student research grant from 2019 that partly supported present study.

\section{References}

Ciobanu, C., N. Cook, C. Kelson, R. Guerin, N. Kalleske, L. Danyushevsky. 2013. Trace element heterogeneity in molybdenite fingerprints stages of mineralization. - Chem. Geol., 347, 175-189.

Ivanov, Zh. 2017. Tectonics of Bulgaria. Sofia, "St. Kliment Ohridski" Univ. Press, 332 p. (in Bulgarian).

Deltchev, A., S. Dimitrov. 1964. Géologie et particularités géochimiques du gisement Babiak - Blagoevgrad. - Ann. Direct. Gén. de Géol., 15, 5-34 (in Bulgarian with French abstract).
Kamenov, B., I. Peytcheva, L. Klain, K. Arsova, Y. Kostitsin, E. Salnikova. 1999. Rila-West Rhodopes Batholith: Petrological and geochemical constraints for its composite character. - Geochem., Mineral., Petrol., 36, 3-27.

Marchev, P., S. Georgiev, R. Raicheva, I. Peytcheva, A. von Quadt, M. Ovtcharova, N. Bonev. 2013. Adakitic magmatism in post-collisional setting: An example from the early-middle Eocene magmatic belt in Southern Bulgaria and Northern Greece. - Lithos, 180-181, 159-180.

Peytcheva, I., M. Stavrev, A. Hikov, S. Chavdarova, T. Vladinova. 2020. LA-ICP-MS U-Pb zircon dating of granites in the area of Vishteritsa pegmatites: implication for timing of fertile magmatism in the Western Rhodopes, Bulgaria. Rev. Bulg. Geol. Soc., 81, 3 (in this volume).

Popov, K., P. Popov. 2019. The Alpine late collisional RilaRhodope Metallogenic Zone of the Balkan Orogenic System. - Rev. Bulg. Geol. Soc., 80, 1, 55-79.

Sarov, S., S. Moskovski, T. Zhelezarski, N. Georgiev, E. Voynova, D. Nikolov, I. Georgiev, V. Valev, N. Markov. 2010. Explanatory Note to the Geological Map of Bulgaria. Scale 1:50 000. Belitsa Map Sheet. Sofia, Ministry of Environment and Water and Bulgarian Geological Survey, 68 p.

Selby, D., R. Creaser. 2004. Macroscale NTIMS and microscale LA-MC-ICP-MS Re-Os isotopic analysis of molybdenite: Testing spatial restrictions for reliable Re-Os age determinations, and implications for the decoupling of Re and Os within molybdenite. - Geochim. Cosmochim. Acta, 68, 3897-3908.

Stavrev M., A. Hikov, I. Peytcheva, E. Stefanova. 2018. Geochemical features of the hydrothermal alterations and basemetal ore mineralization near the village of Babyak, Western Rhodopes (Bulgaria): preliminary results. - Rev. Bulg. Geol. Soc., 79, 3, 59-60.

Stavrev, M., I. Peytcheva, A. Hikov, R. D. Vassileva, A. von Quadt, M. Guillong, V. Grozdev, Y. Plotkina. 2020. Late Cretaceous magmatism in part of the Western Rhodopes (Bulgaria): U-Pb dating on zircon and grossular-andradite garnets. - C. R. Acad. Bulg. Sci., 73, 4, 522-530.

Valkov, V., N. Antova, K. Doncheva. 1989. Granitoids of the Rila-West Rhodopes Batholith. - Geologica Balc., 19, 2, 21-54 (in Russian with English abstract).

von Quadt, A., I. Peytcheva. 2005. The southern extension of the Srednogorie type Upper Cretaceous magmatism in RilaWestern Rhodopes: Constraints from isotope-geochronological geochemical data. - In: Proceedings of the National Conference "GEOSCIENCES 2005”. Sofia, BGS, 113-116. 